\title{
Pusat Komik dan Animasi di Kota Banda Aceh dengan Pendekatan Modern Berkelanjutan
}

\author{
Hanindhifa Azzahra ${ }^{1}$, Zulfikar Taqiuddin ${ }^{2 *}$, Muliadi $^{3}$ \\ ${ }^{1}$ Mahasiswa Jurusan Arsitektur dan Perencanaan, Fakultas Teknik Universitas Syiah Kuala \\ ${ }^{2,3}$ Jurusan Arsitektur dan Perencanaan, Fakultas Teknik Universitas Syiah Kuala \\ *Koresponden email: zulfikartaqiuddin@ unsyiah.ac.id
}

Diterima: 3 Januari 2022

Disetujui : 20 Januari 2022

\begin{abstract}
Comics and Animation is currently one of the media that can raise various themes, ranging from entertainment, education, business, and politics. However, the facilities in Banda Aceh are considered inadequate for this comic and animation activity. In addition, the place to hold comic and animation exhibitions is also not available, this is feared considering that the field of comics and animation requires adequate facilities and proper management. Therefore, this writing aims to create or design a center of comic and animation activities that can be a place or container for the people of Aceh. This Comic and Animation Center will be located in Tentara Siswa Street, Kampung Baru, Baiturrahman District, Banda Aceh City. This design takes the theme of Modern Contemporary and Sustainable Architecture. The use of this theme of Modern Contemporary and Sustainable Architecture recalls the present that not only attaches importance to the architectural style of the present but also the sustainability of the building in the future by reducing the negative environmental impact.
\end{abstract}

Keywords: comic center, animation, modern architecture, sustainable architecture

\begin{abstract}
Abstrak
Komik dan Animasi saat ini menjadi salah satu media yang dapat mengangkat berbagai tema, mulai dari hiburan, pendidikan, bisnis, dan politik. Akan tetapi, fasillitas yang ada di Banda Aceh dirasa tidak memadai untuk aktivitas komik dan animasi ini. Selain itu, tempat untuk mengadakan pameran komik dan animasi juga tidak tersedia, hal ini dikhawatirkan mengingat bidang komik dan animasi ini membutuhkan fasilitas yang memadai dan manajemen yang tepat. Oleh karena itu penulisan ini bertujuan untuk menciptakan atau merancang pusat kegiatan komik dan animasi yang dapat menjadi tempat atau wadah bagi masyarakat Aceh. Pusat Komik dan Animasi ini akan berlokasi di Jalan Tentara Pelajar, Kampung Baru, Kecamatan Baiturrahman, Kota Banda Aceh. Perancangan ini mengambil tema Arsitektur Modern Kontemporer dan Berkelanjutan. Penggunaan tema Arsitektur Modern Kontemporer dan Berkelanjutan ini mengingat masa sekarang yang tidak hanya mementingkan gaya arsitektur masa kini tetapi juga keberlanjutan bangunan tersebut di masa depan dengan mengurangi dampak negatif lingkungan.
\end{abstract}

Kata kunci: pusat komik, animasi, arsitektur modern, arsitektur berkelanjutan

\section{Pendahuluan}

Komik dan animasi di Banda Aceh saat ini sudah berkembang dengan pesat. Seiring perkembangan teknologi, banyak masyarakat yang belajar secara otodidak dan menjual/meng-upload karyanya melalui platform-platform online yang ada seperti Creative Market, Instagram, Webtoon, dan lain-lain sehingga dapat meningkatkan pendapatan dan ide kreatif yang bisa berdampak langsung bagi pembangunan Aceh kedepan. Pada hari Sabtu (11/12/2021), Dinas Kebudayaan dan Pariwisata Aceh membuka ruang kreatif dengan menggelar Malam Apresiasi Seni Animasi Aceh yang bertujuan untuk menghimpun animator yang ada di Aceh dan para animator tersebut dapat menginformasikan tentang budaya dan wisata yang ada di Aceh kepada masyarakat umum.

Kepala Dinas Kebudayaan dan Pariwisata Aceh menjelaskan bahwa, dengan kegiatan seperti ini dapat memberi ruang kepada generasi muda dalam berkarya meskipun selama ini belum ada wadah khusus untuk mengembangkan ilmu dan berbagi informasi, serta kolaborasi bagi para animator Aceh [1]. Dari hal tersebut dapat disimpulkan bahwa peminat komik dan animasi di Banda Aceh semakin banyak tetapi untuk menampung aktivitas tersebut belum tersedia. Sehingga pusat komik dan animasi ini akan menjadi bangunan yang dapat mewadahi kegiatan belajar membuat komik dan animasi 
yang akan mewadahi kegiatan pameran yang tidak hanya menjadi hiburan positif, tetapi juga dapat meningkatkan ekonomi.

Perancangan Studio Komik dan Animasi ini menggunakan tema Arsitektur Kontemporer Berkelanjutan. Tema ini dipilih karena Arsitektur Kontemporer tidak terpaku dengan satu gaya dan akan selalu berubah mengikuti perkembangan zaman sehingga bersifat dinamis, sama halnya dengan dunia komik dan animasi ini dimana tidak ada batasan dalam berkarya. Lalu, berkelanjutan yang berarti tidak hanya memikirkan masa sekarang tetapi, juga memikirkan keberlangsungan bangunan tersebut di masa yang akan datang.

\section{Lokasi Perancangan}

Lokasi Perancangan Pusat Komik dan Animasi di Banda Aceh ini terletak di Jalan Tentara Pelajar, Kampung Baru, Kecamatan Baiturrahman, Kota Banda Aceh (Terminal Labi-labi Keudah)

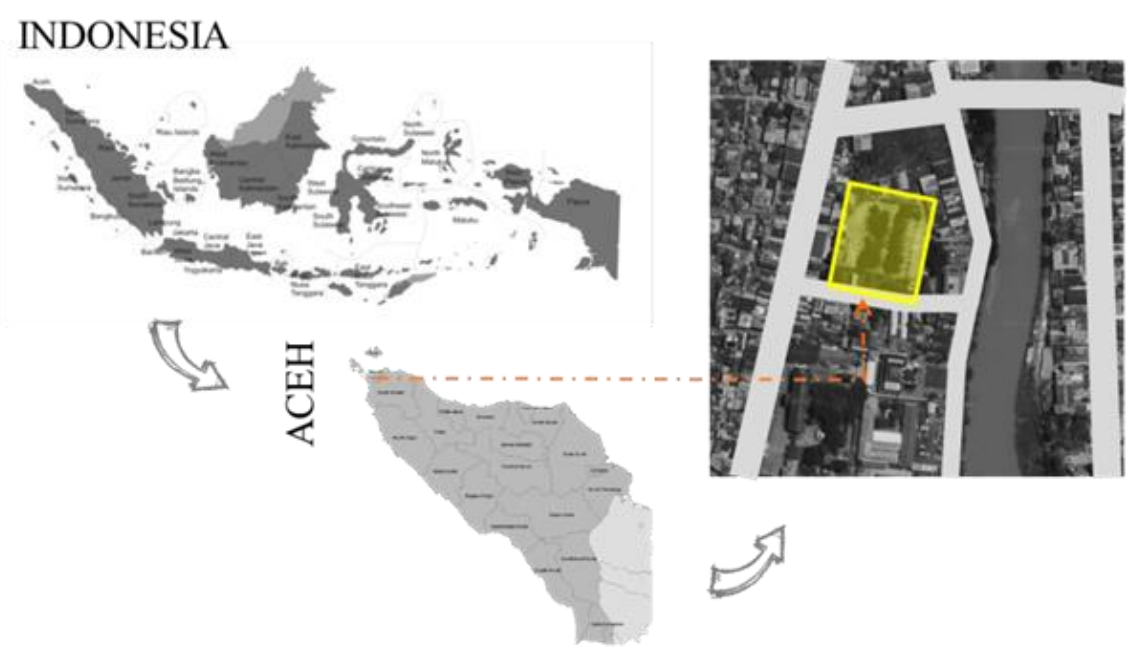

Gambar 1. Lokasi perancangan

Sumber: Google Image dan Google Earth, 2021

Lahan ini memiliki luas 1,1 Ha yang berada di peruntukan lahan perdagangan dan jasa dengan pemandangan Sungai Krueng Aceh sehingga sangat tepat menjadi lokasi Pusat Komik dan Animasi [2]. Gambar 2 memperlihatkan batasan pada lokasi perancangan ini.

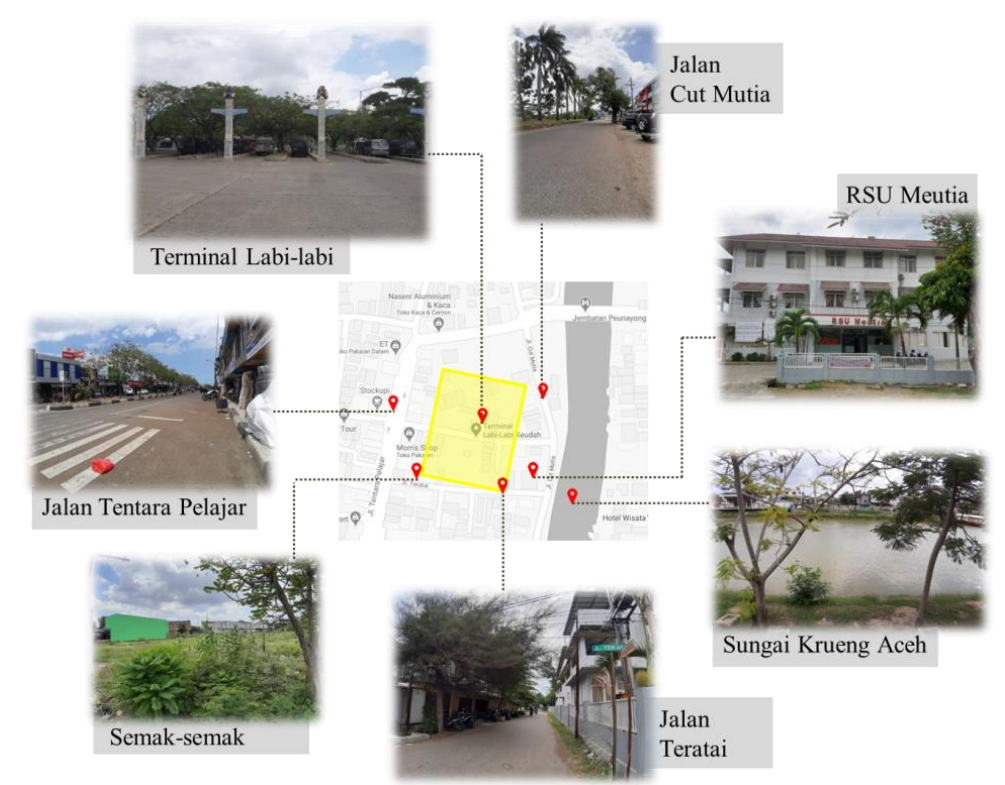

Gambar 2. Batasan site

Sumber: Data Penelitian dan Google Map, 2021 


\section{Tinjauan Tema Perancangan}

Tema perancangan yang digunakan adalah arsitektur modern yang berkhusus di kontemporer dan arsitektur berkelanjutan. Pendekatan kontemporer pada arsitektur terdapat 2 macam, yang pertama adalah waktu dimana bermakna bukan yang dikenal di masa lalu atau di masa depan, tetapi arsitektur yang dibuat dan dikenal pada hari ini. Yang kedua yaitu bentuk dimana bermakna bangunan monumental yang dikenal sebagai arsitektur kontemporer pada masanya tersebut diambil menjadi suatu bentuk arsitektur [3].

Dalam mengaplikasikan teori pada rancangannya, Richard Meier menggunakan konsep dan metode desain Modern Arsitektur sebagai berikut :

a) Pada denah dan tampak dikomposisikan bentuk geometrik dasar

b) Pemakaian pola grid

c) Pemakaian daylighting

d) Membangun keterhubungan antar ruang

e) Membangun hubungan arsitektur dengan konteks lingkungan sekitarnya (arsitektur kontekstual)

f) Pada elemen garis dan bidang, dilakukan repetisi [4].

Terdapat 3 tanda bahwa bangunan tersebut merupakan arsitektur kontemporer yaitu :

a) Memiliki karakter khusus pada ekspresi bangunan

b) Memiliki lingkungan yang berbeda dengan sekitarnya

c) Dan memiliki rasa kuat pada penghayatan, impresi, dan kesan [5].

Arsitektur hijau merupakan arsitektur yang mengonsumsi sumber daya alamnya seminimal mungkin, didalamnya termasuk energi, air, material, dan dampak negatif lingkungan yang ditimbulkan juga sedikit [6]. Untuk mempertahankan ekosistem di bumi, arsitektur hijau merupakan langkah pertama, lalu istilah arsitektur berkelanjutan pun dikenal. Secara sederhananya, konsep arsitektur berkelanjutan yaitu kebutuhan masa kini yang dapat dipenuhi oleh pembangunan tersebut lalu kebutuhan di masa depan yang dapat dipenuhi oleh pembangunan dengan kemampuan generasi mendatang [7]. Untuk membantu melestarikan ekosistem sekitar dan sumber daya alam maupun flora dan fauna yang terdapat didalamnya, diterapkan prinsip Arsitektur Berkelanjutan pada bangunan tersebut sehingga arsitektur berkelanjutan dapat diartikan sebagai desain yang berwawasan lingkungan [8].

Perancangan ini memiliki studi banding yang nantinya beberapa konsep dari bangunan tersebut akan diterapkan ke perancangan ini. Studi banding yang dipilih adalah RUS Animation Studio, Seoul Animation Center, Museum Tsunami Aceh, dan Bullitt Center.

\subsection{Raden Umar Said (RUS) Animation Studio}

RUS Animation Studio ini merupakan bagian dari SMK Raden Umar Said yang berfungsi sebagai tempat belajar dan unit produksi film animasi. Studio ini dibangun di Kabupaten Kudus, Jawa Tengah.

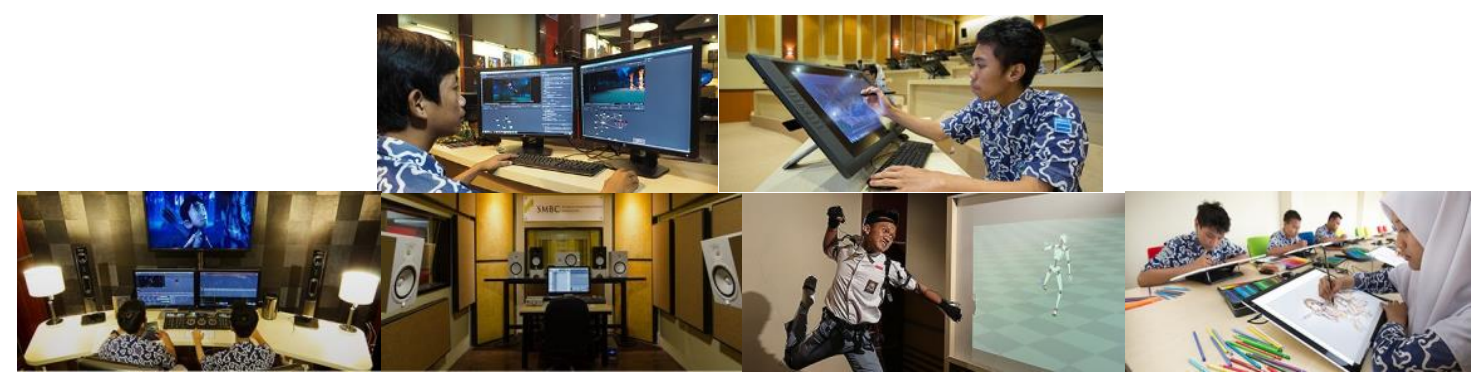

Gambar 3. RUS Animation Studio

Sumber: RUS Animation Studio, 2020

Terdapat berbagai ruang yang dapat mewadahi berbagai aktivitas pada studio ini, yaitu studio gambar, ruang produksi, visual effect studio, color grading studio, sound studio, motion capture studio, art studio, dan lain-lain [9]. Nantinya ruang-ruang ini yang akan diterapkan pada Pusat Komik dan Animasi. 


\subsection{Seoul Animation Center}

Seoul Animation Center merupakan fasilitas animasi pertama yang didedikasikan di Kota Seoul, Korea Selatan dan juga merupakan rumah bioskop pertama di Korea yang khusus untuk pemutaran film animasi.
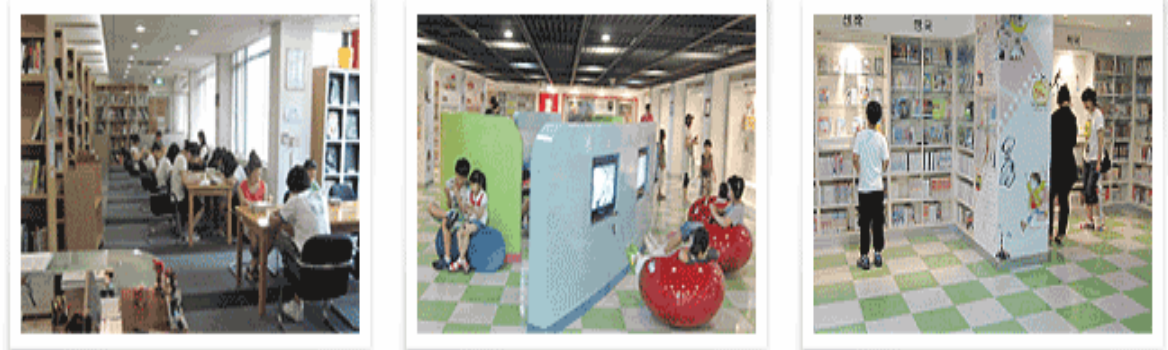

Gambar 4. Seoul Animation Center

Sumber: Seoul Animation Center, 2020

Tujuan Ani-Cinema adalah untuk memudahkan pasokan film animasi domestik untuk bioskop dan mempromosikan karya animasi dengan menggelar berbagai festival film. Selain AniCinema,terdapat juga fasilitas lain yaitu perpustakaan komik [10].

\subsection{Museum Tsunami Aceh}

Museum Tsunami Aceh merupakan museum yang memiliki gaya arsitektur kontemporer dan dirancang oleh salah satu arsitek terkenal Indonesia yaitu Ridwan Kamil. Museum Tsunami ini diresmikan pada tahun 2009. Fungsi museum ini yaitu sebagai salah satu cara mengenang kejadian tsunami di Aceh pada tanggal 26 Desember 2004.

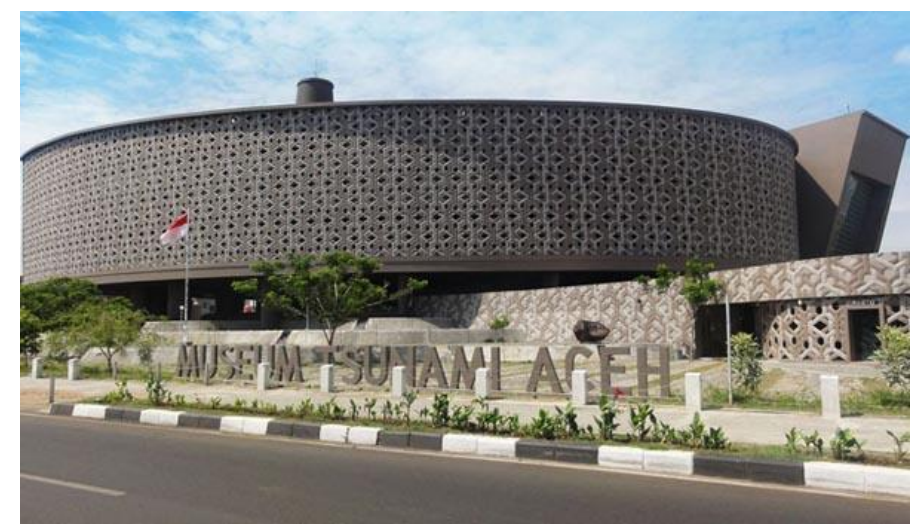

Gambar 5. Museum Tsunami Aceh

Sumber: Google Image, 2018

Beberapa prinsip yang terdapat di Museum Tsunami Aceh, yaitu :

1. Bangunan berdiri dengan kokoh sehingga seperti bentuk kapal.

2. Gubahan massa yang berbenuk oval terlihat tidak kaku karena yang dianalogikan dari bentuk kapal.

3. Dibuat void pada tengah bangunan yang ditutup oleh atap transparan (skylight) sehingga memberikan kesan terbuka.

4. Fasadnya dilapisi secondary skin dan didalamnya menggunakan curtain wall [11].

\subsection{Bullitt Center}

Bangunan ini dirancang oleh Miller Hull Partnership [12]. Bullitt Center adalah bangunan yang pertama dari jenis ini yang menerima sertifikasi Living Building dari Living Building Challenge International Living Future Institute. Bangunan ini memiliki 575 panel surya, yang menghasilkan $60 \%$ dari kebutuhan energi bangunan. Konstruksi bangunan juga menggunakan kayu dari hutan yang dipanen secara berkelanjutan [13]. 


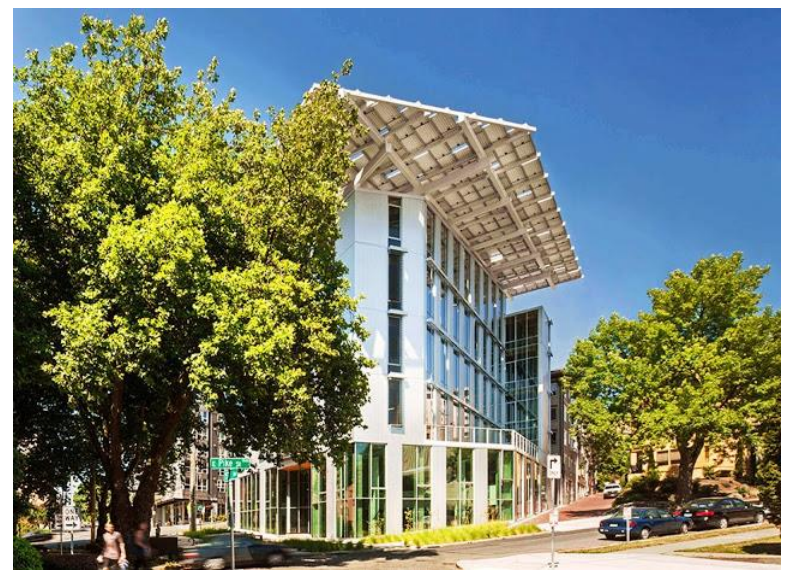

Gambar 6. Bullitt Center

Sumber: Bullitt Center, 2013

Beberapa fitur-fitur yang terdapat pada Bullitt Center :

- Sumber energi listrik berasal dari panas matahari melalui 575 panel surya yang terdapat pada bangunan.

- Untuk penyiraman air tanaman menggunakan grey water (air bekas).

- Terdapat drum-drum untuk menampung air hujan sehingga curah hujan yang tinggi di Kota Seattle dapat dimanfaatkan sebaik mungkin. Air hujan yang dapat ditangkap bangunan sebesar $39 \%$ [14].

\section{Arsitektur Kontemporer Berkelanjutan pada Bangunan Pusat Komik dan Animasi}

\subsection{Ide Bentuk}

Ide bentuk diambil dari bentuk lingkaran yang bermakna gabungan dari komik dan animasi yang tidak dapat dipisahkan. Lalu bentuk ini dibagi menjadi dua sehingga membentuk setengah lingkaran. Bentuk ini juga disesuaikan dengan gaya arsitektur modern kontemporer berkelanjutan, terlihat dari bentuk lingkaran yang dinamis.

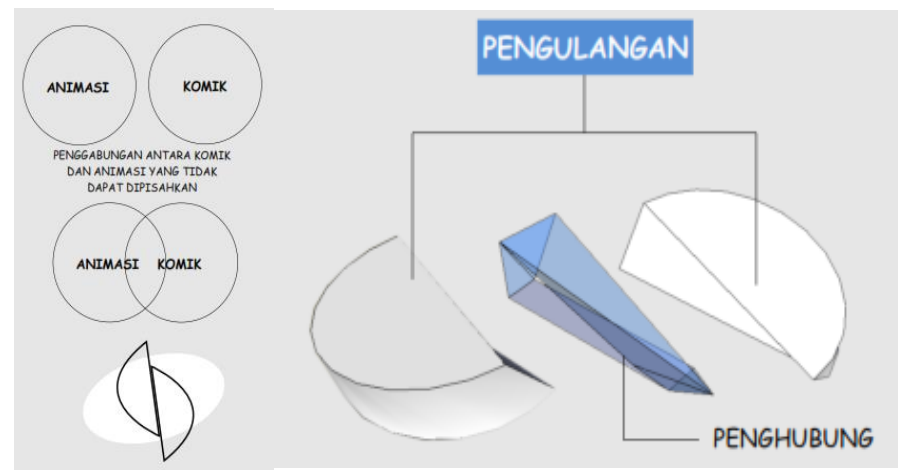

Gambar 7. Ide bentuk

Sumber: Data penelitian, 2021

\subsection{Implementasi Konsep pada Rancangan}

Pada eksterior bangunan menggunakan secondary skin yang terlihat bergelombang yang bermakna alur dari sebuah cerita yang dibuat mengalir dan dinamis. Di atasnya juga terdapat tanaman merambat yang memberikan kesan tidak kaku dan fresh. Tanaman yang ditanam ini akan tumbuh berbeda-beda sehingga terlihat berirama. Pada bangunan juga menggunakan skylight sehingga memberikan kesan terbuka pada interior bangunan. 


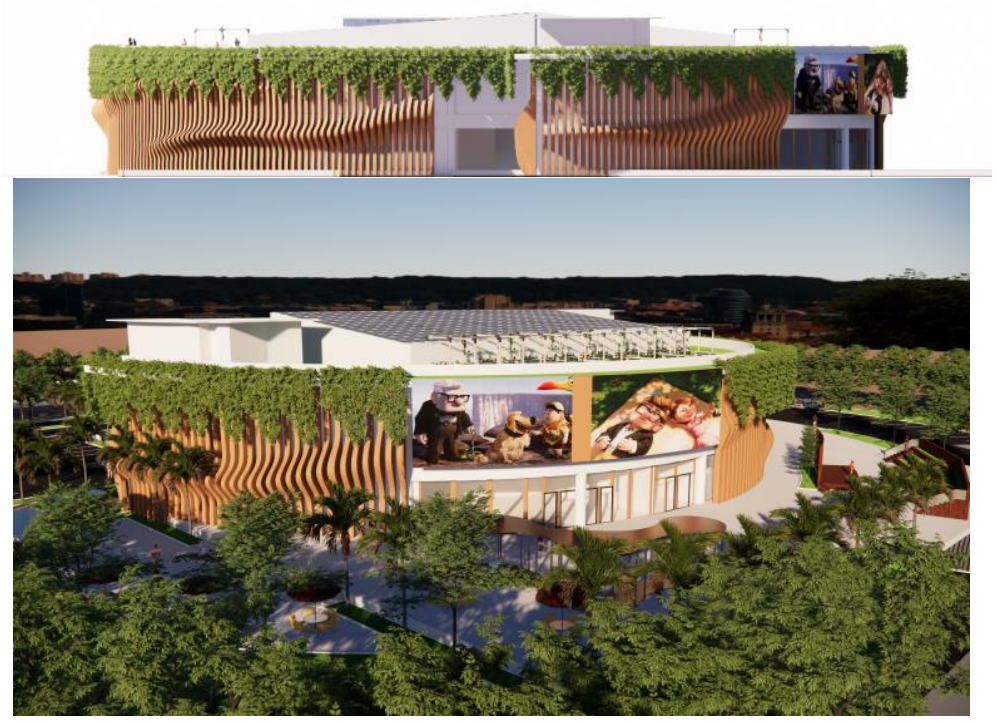

Gambar 8. Eksterior bangunan

Sumber: Data penelitian, 2021

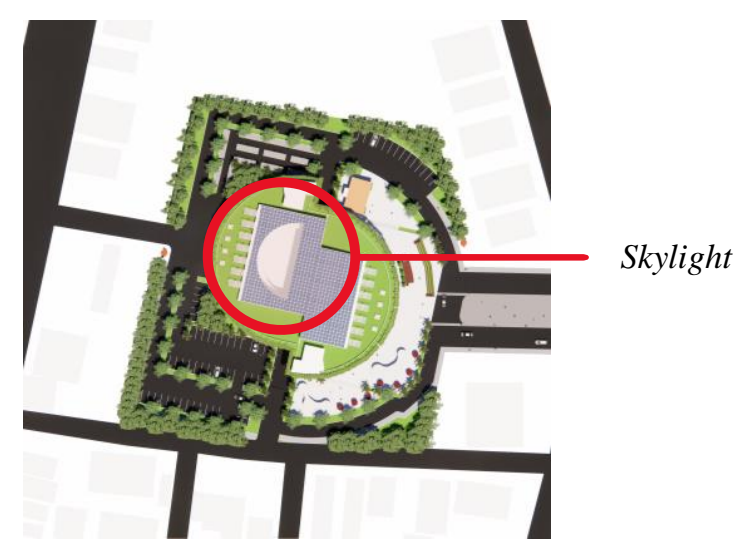

Gambar 9. Tampak atas bangunan Sumber: Data penelitian, 2021

Terdapat banyak aktivitas-aktivitas yang tidak hanya menghibur tetapi juga mendidik pada rancangan ini. Aktivitas-aktivitas tersebut antara lain kelas belajar komik dan animasi, theater untuk menonton film animasi, tempat mengadakan pameran, membaca di perpustakaan, dan lain-lain.

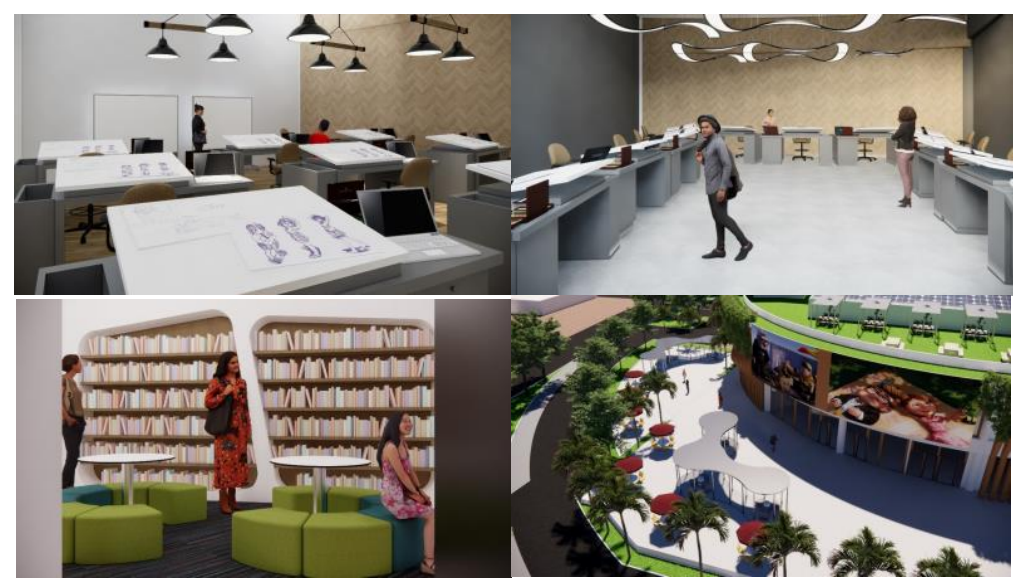

Gambar 10. Area yang terdapat pada rancangan

Sumber: Data penelitian, 2021 


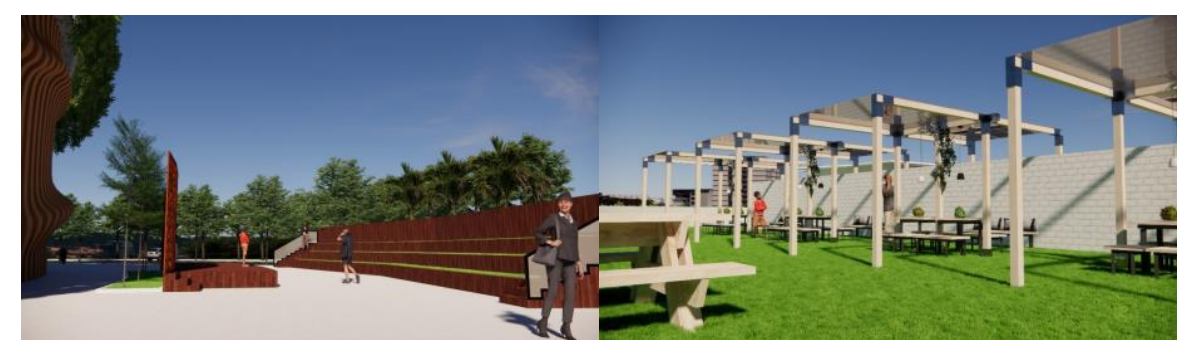

Gambar 11. Area yang terdapat pada rancangan Sumber: Data penelitian, 2021

Pada bangunan Pusat Komik dan Animasi ini akan menggunakan dinding bata yang dilapisi beton dengan finishing cat putih. Pada dinding eksterior bangunan juga menggunakan material solartuff sebagai pengganti kaca. Pada secondary skin menggunakan material UPVC dan untuk material rangka atap menggunakan besi hollow bulat.

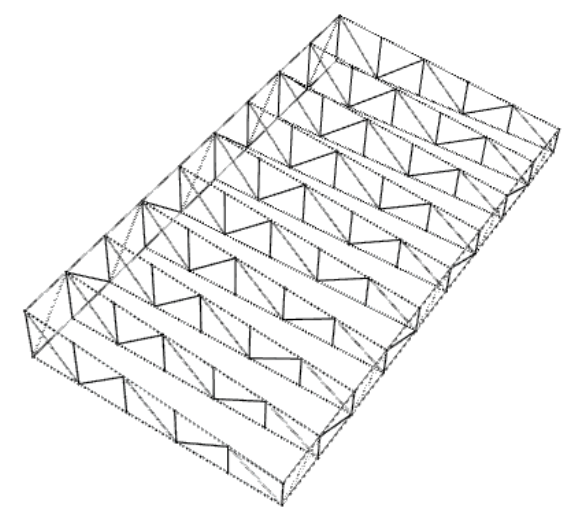

Gambar 12. Rangka atap

Sumber: Data penelitian, 2021

Pada atap juga menggunakan struktur green roof dan setengah pelana dengan material UPVC dan solartuff pada bagian void (skylight).

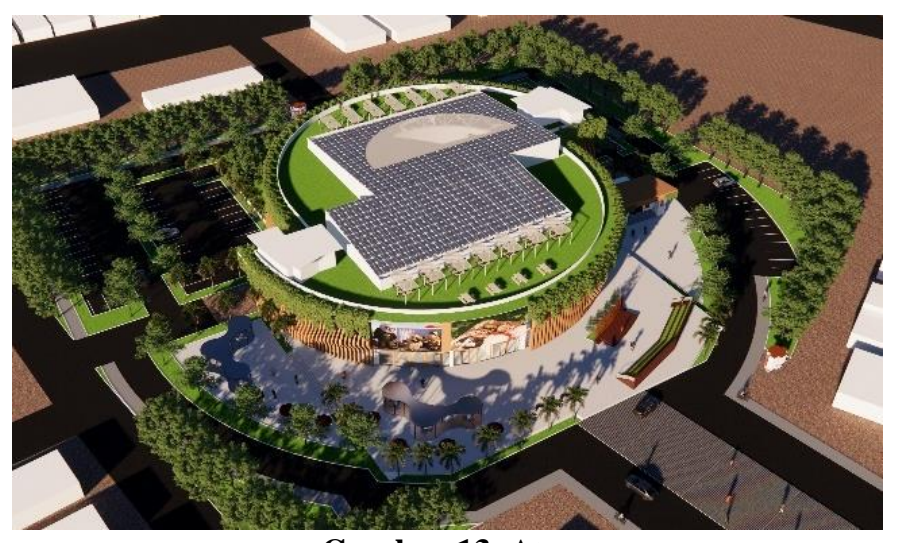

Gambar 13. Atap

Sumber: Data Penelitian, 2021

Untuk material lantai yang dipilih adalah keramik dan parket. Keramik memiliki kelebihan yaitu kuat, tahan lama, memiliki banyak varian desain dan warna, juga pemeliharaanya pun lebih mudah. Sedangkan lantai parket memiliki kelebihan yaitu memberikan suhu yang hangat pada ruangan dan instalasinya tergolong sangat mudah [15]. Pemilihan material ini sangat sesuai dengan tema arsitektur kontemporer berkelanjutan. 


\subsection{Utilitas}

Dengan memanfaatkan curah hujan yang tinggi di lokasi, sistem daur ulang akan digunakan pada pembuangan air hujan sehingga air tersebut dapat digunakan kembali untuk menyiram vegetasi. Terdapat panel surya sehingga dapat menghemat energi pada bangunan.

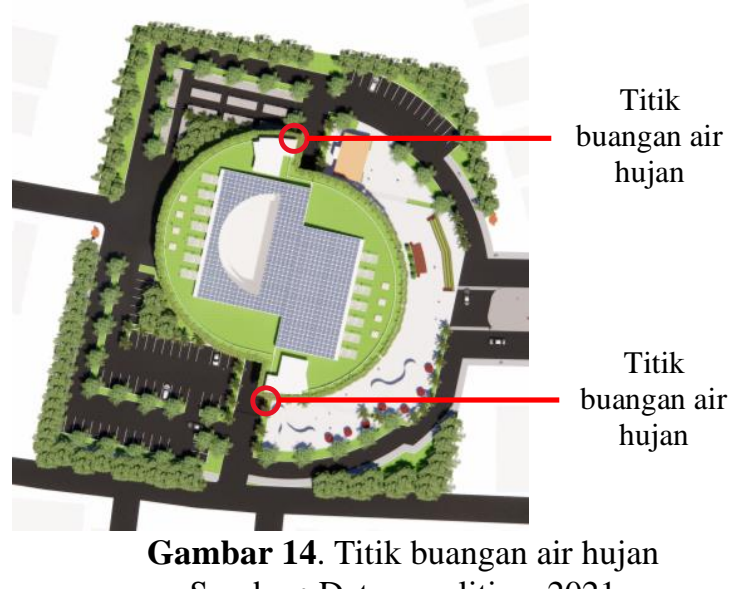

Sumber: Data penelitian, 2021

\section{Kesimpulan}

Perancangan Pusat Komik dan Animasi ini diharapkan mampu menjadi solusi bagi masyarakat Aceh, khususnya bagi para pegiat komik dan animasi untuk belajar dan menempa ilmu Animasi dan komik lebih intens dan juga sebagai wadah untuk melakukan kegiatan pameran dan komunitas lainnya. Dengan menggunakan tema Arsitektur Modern, khususnya Arsitektur Modern Kontemporer yang Berkelanjutan dan juga mempertimbangkan lokasi tapak yang berada di wilayah beriklim tropis, penggunaan tema ini bertujuan selain mengurangi kerusakan pada lingkungan sekitar sehingga dapat mempertahankan sumber daya alam demi keberlangsungan bangunan kedepan sehingga bisa bertahan lebih lama dan juga bisa mempertahankan bentuk bangunan dengan konsep modern dan sederhana.

\section{Daftar pustaka}

[1] Disbudpar Aceh, Disbudpar Aceh Buka Ruang Kreatif Lewat Kegiatan Apresiasi Seni Animasi. Banda Aceh, 2021.

[2] Qanun Kota Banda Aceh, Qanun Kota Banda Aceh Nomor 2 Tahun 2018, Banda Aceh, 2018.

[3] R. R. Rasmi, "Arsitektur Kontemporer (MK: Teori Desain Arsitektur)," Sekolah Arsitektur, Perencanaan dan Pengembangan Kebijakan, Institut Teknologi Bandung, 2013.

[4] A. Jerobisonif, dkk., "Konsep dan Metode Desain Aristektur Richard Meier," Gewang vol. 2, no. 2, hal. 71-80, 2020.

[5] Gunawan, "Reaktualisasi Ragam Art Deco Dalam Arsitektur Kontemporer," Universitas Sam Ratulangi, Manado, 2011.

[6] K. T. Harso, "Green Architecture: Pengantar Pemahaman Arsitektur Hijau di Indonesia, 2010.

[7] I. Prayoga, "Desain Berkelanjutan (Sustainable Design)," E-Jurnal, Jurusan Arsitektur, Universitas Pandanaran, 2013.

[8] M. N. Amin, "Penerapan Prinsip Arsitektur Berkelanjutan pada Perencanaan Kampung Pangan Lestari di Mojosongo, Kecamatan Jebres, Kota Surakarta,” Surakarta: Jurnal Senthong, 2019.

[9] RUS Animation, RUS Animation Studio. Kudus, 2020.

[10] Ani Seoul, Seoul Animation Center. Seoul, 2020.

[11] I. A. Nursandi dan A. Ashadi, "Kajian Konsep Arsitektur Kontemporer Pada Bangunan Museum Tsunami Aceh," Border: Jurnal Arsitektur, vol. 3, no. 2, hal. 87-96, 2021.

[12] H. B. Alexander, "Ini 5 Bangunan Rendah Karbon di Dunia," Jakarta, 2021.

[13] Arsitur Studio, "Sustainable Architecture atau Arsitektur Berkelanjutan,” 2020.

[14] Bullitt Foundation, Bullitt Center. Seattle, 2013.

[15] Archifynow, Pemilihan Material Lantai untuk Rumah Anda. Jakarta, 2020. 